\title{
Effect of Aqueous Extract of Selected Plants on Liver, Bone and Kidney Markers of 7,12-Dimethylbenz(A)Anthracene (DMBA) Treated Albino-Rats
}

\section{Akuru UB*, Amadi BA and Abbey BW}

Department of Biochemistry, University of Port Harcourt, Nigeria

*Corresponding author: Akuru Udiomine Brantley, Department of Biochemistry, University of Port Harcourt , Choba, Port Harcourt, Nigeria, Tel: 7065563343; Email: minebrantley@gmail.com

\section{Research Article \\ Volume 4 Issue 2}

Received Date: February 27, 2019

Published Date: March 14, 2019

DOI: $10.23880 / \mathrm{ijbp}-16000150$

\section{Abstract}

Breast cancer is an abnormal cell growth of the breast tissue and upon metastasis affects other organs of the body such as the liver, bones and lungs. The aim of this study is to investigate the effect of aqueous extract of Sorghum vulgare leafsheath, Eremomastax polysperma and Brillantaisia owariensis leaves on the liver, bone and kidney markers of 7,12dimethylbenz[a]anthracene (DMBA) treated albino-rats. Sixty-three female albino rats weighing 120-250g, were used for the study for a period of 15 weeks. The animals were grouped into nine groups of seven animals each. Group I (control) was fed with normal feed. Groups II to IX, were orally administered 20mg DMBA/kg to induce breast cancer. Group II was untreated; Group III was treated with tamoxifen (6.6mg/kg). Groups IV- IX were treated with $500 \mathrm{mg} / \mathrm{kg}$ Sorghum vulgare, $1000 \mathrm{mg} / \mathrm{kg}$ Sorghum vulgare, 500mg/kg Eremomastax polysperma; 1000mg/kg Eremomastax polysperma, $500 \mathrm{mg} / \mathrm{kg}$ Brillantaisia owariensis and $1000 \mathrm{mg} / \mathrm{kg}$ Brillantaisia owariensis respectively. Treatment with the various extract showed significant decrease $(\mathrm{p} \leq 0.05)$ of total bilirubin, calcium and urea concentration, aspartate aminotransferase, alanine aminotransferase and alkaline phosphatase activities when compared to DMBA-untreated group. Albumin concentration of the treated groups was significantly higher $(\mathrm{p} \leq 0.05)$ than the DMBA-untreated animals. Gamma glutamyl transferase and acid phosphatase activities, uric acid, electrolytes and total protein concentration showed no significant difference $(\mathrm{p} \leq 0.05)$ between the treated groups and the DMBA-induced animals. The present study demonstrates that the extract of the plants was able to reduce any burden posed on the liver by DMBA-induced breast cancer.

Keywords: Breast Cancer; Liver Function Test; Kidney Markers; Bone Markers DMBA 


\section{International Journal of Biochemistry \& Physiology}

\section{Introduction}

7,12-dimethylbenz[a]anthracene(DMBA) is a polycyclic-aromatic hydrocarbon that acts as an immunosuppressant and it used to induce various cancers such as breast, lungs, oral and skin [1]. Cancer is one of the foremost causes of morbidity and mortality worldwide [2]. Cancer occurs when there is an uncontrolled cell division and proliferation.

Breast cancer (one of the cancers induced by DMBA) is the second most common cancer among women globally [1]. Breast cancer when developed, usually spread to the bones, lungs, and liver. Approximately $40-50 \%$ of women with metastatic breast cancer will have liver metastasis at some point during the course of their disease [3].

Chemotherapeutic treatment is used routinely for cancer treatment but some toxicity might be associated with chemotherapeutic drug usage. Plant-derived therapeutic products have been propounded for cancer treatment such as vinca alkaloids, taxanes, epippodphyllotoxins and camptothecin derivatives. Plants been a reservoir of natural bioactive compounds provide chemoprotective potentials against cancer [2]. The plants examined were Sorghum vulgare, Brillantaisia owariensis and Eremomastax polysperma. Sorghum vulgare is of the Poacea (grass) family. Sorghum vulgare leaf-sheath have been shown to contain phytate, tannins, cyanide, flavonoids [4], saponins, phenols and ribalinidine (an alkaloid) [5]. Whereas Eremomatax polysperma and Brillantaisia owariensis belongs to the Acanthaceae family. These species contain flavonoids, alkaloids, phenols, tannins, saponins and also have antioxidant properties [57]. Hence this study was aimed at determining the effect of aqueous extract of selected plants on the liver, kidney and bone markers of DMBA - treated rats.

\section{Methodology}

\section{Collection of Plant sample}

The plants; Sorghum vulgare leaf sheath was bought in mile 3 market while Eremomastax polysperma and Brillantaisia owariensis were gotten from a farm at Rumokoro (Lat 4.88999; long 6.96922) all in Port Harcourt, Nigeria. The plants were identified with voucher numbers: UPH/V/1325(Brillantaisia owariensis), UPH/V/1326 (Sorghum vulgare, synonyms Sorghum bicolor) and UPH/V/1346 (Erempmastax polysperma). They were dried and ground into fine powder with a blender and stored in an air tight container.

\section{Preparation of aqueous extract of the plants}

The plants were ground and the powder was macerated in distilled water for $12 \mathrm{hrs}(1 \mathrm{~kg} / \mathrm{l})$. The macerate was filtered using Whatman filter paper (No 3), and the filtrate was concentrated using a rotary evaporator $\left(60^{\circ} \mathrm{C}\right)$ to obtain concentrated crude extract. The extract was stored in a freezer until further use.

\section{Experimental animals and design}

Sixty-three albino rats were obtained from the animal house of the Department of Biochemistry, University of Port Harcourt. The animals were distributed randomly into nine groups of seven animals each. They were housed and fed ad libitum with water and growers mash and was allowed for a week for acclimatization. The experiment was conducted for a period of 14 weeks and the animals were treated as follows:

I. Control: normal rats fed with normal rat feed

II. DMBA: Carcinogenic control, animals given $20 \mathrm{mg} / \mathrm{kg}$ of 7,12-dimethyl benz(a)anthracene

III. DMBA STD: animals given 20mg of 7,12-dimethyl benz(a)anthracene and treated with a standard drug (tamoxifen $6.6 \mathrm{mg}) / \mathrm{kg}$

IV. DMBA SVL500: animals given 20mg of 7,12-dimethyl benz(a)anthracene and treated with $500 \mathrm{mg} / \mathrm{kg}$ of Sorghum vulgare leaf sheath.

V. DMBA SVL1000: animals given 20mg of 7,12dimethyl benz(a)anthracene and treated with $1000 \mathrm{mg} / \mathrm{kg}$ of Sorghum vulgare leaf sheath.

VI. DMBA E.P.500: animals given 20mg of 7,12-dimethyl benz(a)anthracene and treated with $500 \mathrm{mg} / \mathrm{kg}$ of Eremomastax polysperma

VII. DMBA E.P.1000: animals given 20mg of 7,12-dimethyl benz(a)anthracene and treated with $1000 \mathrm{mg} / \mathrm{kg}$ of Eremomastax polysperma

VIII.DMBA B.W. 500: animals given $20 \mathrm{mg}$ of 7,12dimethyl benz(a)anthracene and treated with $500 \mathrm{mg} / \mathrm{kg}$ of Brillantaisia owariensis

IX. DMBA B. W. 1000: animals given $20 \mathrm{mg}$ of 7,12dimethyl benz(a)anthracene and treated with $1000 \mathrm{mg} / \mathrm{kg}$ of Brillantaisia owariensis

\section{Induction of cancer}

Mammary gland tumours were induced by a single dose of $20 \quad \mathrm{mg}$ of 7,12dimethylbenz(a)anthracene(DMBA) diluted in soy oil (1 $\mathrm{mL}$ ) given intragastrically by gavage. Physical examination was performed monthly. Each rats' mammary gland was checked by inspection and touching. At the $8^{\text {th }}$ week after DMBA administration, biopsy test was done to ascertain that the tumours formed are cancerous [8]. The Mammary tumours were cut and 


\section{International Journal of Biochemistry \& Physiology}

representative fragments of the tumours was fixed in $10 \%$ formaldehyde and paraffin embedded. The blocks were sectioned every $5 \mathrm{~mm}$, and slides was prepared with haematoxylin-eosin stain and examined using light microscopy $[8,9]$. After the induction of cancer (and left for 8 weeks before treating with the extracts), the animals were treated for the next six weeks with aqueous extract of different plants and the standard drug. The first group was the control; group II received $20 \mathrm{mg}$ DMBA/ $\mathrm{kg}$ to induce cancer; Group III received 20mg DMBA/kg and treated with tamoxifen $(6.6 \mathrm{mg} / \mathrm{kg})$. Groups IV, V, VI, VII, VIII and IX received 20mg DMBA and treated with different concentration of aqueous extract of the various plants.

All drugs were administered orally for duration of 6 weeks. At the end of the study, the rats were weighed, fasted overnight and anaesthetized by exposure to chloroform. They were sacrificed and their blood samples were collected for biochemical analysis.

\section{Determination of liver function}

Alanine aminotransferase (ALT) and Aspartate aminotransferase (AST) activities were determined spectrophotometrically at $546 \mathrm{~nm}$. Alkaline phosphatase (ALP) activity was determined spectrophotometrically at $590 \mathrm{~nm}$. Total Protein (TP) was determined and the absorbance read at $540 \mathrm{~nm}$ in a spectrophotometer. Albumin (ALB) concentration was measured spectrophotometrically at $630 \mathrm{~nm}$, bilirubin concentration was determined and absorbance read at $590 \mathrm{~nm}$ in a spectrophotometer. Whereas GGT activity was determined using Szasz and Teitz method, and absorbance read at $630 \mathrm{~nm}$ in a microplate reader.

\section{Kidney function test}

Uric acid was determined using modified trinder peroxidase assay and absorbance read at $540 \mathrm{~nm}$ in a microplate reader. Urea was determined using spectrophotometric method at $546 \mathrm{~nm}$. Creatinine was determined using picric acid method and absorbance read in a spectrophotometer at $492 \mathrm{~nm}$.

\section{Electrolyte Determination}

Potassium and chloride were determined and absorbance read at $540 \mathrm{~nm}$ using a microplate reader. Sodium Determination was a slight modification of Maruna [10] and Trinder [11] method and absorbance read at $550 \mathrm{~nm}$ in a spectrophotometer. Calcium was estimated using colorimetric method and absorbance read at 578 in a spectrophotometer.

\section{Bone marker determination}

Acid Phosphatase determined using Hillman [12] method and absorbance read using a microplate reader at $540 \mathrm{~nm}$.

\section{Statistical analysis}

Data was represented as mean \pm SEM, and subjected to One-way Analysis of Variance (ANOVA) using Statistical software SPSS. A level of $\mathrm{p} \leq 0.05$ was considered as statistically significant.

\section{Results}

\section{Liver capacity test}

Table 1-4 demonstrates the results of liver capacity test of DMBA administered albino rats, given aqueous concentrate of the different plants. AST activity (Table 1) for DMBA and DMBA EP500 groups was essentially increased $(p \leq 0.05)$ when differentiated to the other groups. For ALT activity, DMBA group had fundamentally increased ( $p \leq 0.05$ ) ALT activity when differentiated to animals in the other groups. While that of ALP activity, there was no significant distinction $(p \leq 0.05)$ in all the groups.

Table 2 demonstrates the Bilirubin concentration of DMBA administered albino rats, given aqueous concentrate of the different plants. For total bilirubin concentration, DMBA E.P.500 $(19.00 \pm 0.50 \mu \mathrm{mol} / \mathrm{L})$ group was significantly increased $(\mathrm{p} \leq 0.05)$ when contrasted to control $(12.96 \pm 2.16 \mu \mathrm{mol} / \mathrm{L})$ and DMBA STD group $(13.60 \pm 0.60 \mu \mathrm{mol} / \mathrm{L}) . \quad$ DMBA $\quad$ E.P1000 $\quad(10.43 \pm 0.82$ $\mu \mathrm{mol} / \mathrm{L})$ and DMBA BW1000 (11.53 $\pm 0.16 \mu \mathrm{mol} / \mathrm{L})$ groups were significantly lower $(p \leq 0.05)$ than the DMBA $(15.43 \pm 1.61 \mu \mathrm{mol} / \mathrm{L})$ untreated group. DMBASVL500 $(13.56 \pm 1.23 \mu \mathrm{mol} / \mathrm{L}), \quad$ DMBASVL1000 $\quad(13.86 \pm 1.06$ $\mu \mathrm{mol} / \mathrm{L})$ had lower values than DMBA $(15.43 \pm 1.61$ $\mu \mathrm{mol} / \mathrm{L}$ ) untreated group, though not significantly different $(\mathrm{p} \leq 0.05)$. In conjugated bilirubin concentration, DMBA E.P $500 \quad(13.43 \pm 0.69 \mu \mathrm{mol} / \mathrm{L})$ group was significantly increased $(\mathrm{p} \leq 0.05)$ when contrasted to control, DMBA $(8.53 \pm 1.41 \mu \mathrm{mol} / \mathrm{L})$ untreated and DMBASTD $(8.10 \pm 0.80 \mu \mathrm{mol} / \mathrm{L})$ groups.

Albumin and Total protein concentration of DMBA administered albino rats, given aqueous concentrate of the different plants is appeared on Table 3. There was no significant contrast $(\mathrm{p} \leq 0.05)$ within the groups for Total protein concentration. 


\section{International Journal of Biochemistry \& Physiology}

For albumin concentration, DMBASVL500 (37.00 $\$ 1.15$ $\mathrm{g} / \mathrm{L})$, DMBASVL1000 (37.33 $\pm 0.66 \mathrm{~g} / \mathrm{L})$ and DMBA BW500 $(35.56 \pm 2.60 \mathrm{~g} / \mathrm{L})$ had higher values $(\mathrm{p} \leq 0.05)$ when contrasted to the control $(32.33 \pm 0.88 \mathrm{~g} / \mathrm{L})$ and DMBA untreated $(31.66 \pm 0.88 \mathrm{~g} / \mathrm{L})$ groups. The other treated groups had higher values also, though not significantly different $(\mathrm{p} \leq 0.05)$.
Table 4 demonstrates the GGT (U/L) activity of DMBA administered albino rats, given aqueous concentrate of the different plants. There was a noteworthy reduction $(p \leq 0.05)$ within the groups in the DMBAE.P1000and DMBA BW500 group when differentiated to the control, DMBA and DMBASTD groups.

\begin{tabular}{|c|c|c|c|c|}
\hline S/N & Groups & AST(U/L) & ALT(U/L) & ALP(U/L) \\
\hline I. & Control & $41.33 \pm 13.54^{\mathrm{a}}$ & $14.80 \pm 3.06^{\mathrm{a}}$ & $51.33 \pm 4.33^{\mathrm{a}}$ \\
\hline II. & DMBA & $63.33 \pm 8.56^{\mathrm{ac}}$ & $30.66 \pm 0.66^{\mathrm{b}}$ & $52.00 \pm 2.30^{\mathrm{b}}$ \\
\hline III. & DMBA STD & $41.66 \pm 3.17^{\mathrm{a}}$ & $18.66 \pm 0.66^{\mathrm{a}}$ & $47.33 \pm 1.33^{\mathrm{c}}$ \\
\hline IV. & DMBASVL500 & $47.00 \pm 2.88^{\mathrm{a}}$ & $19.33 \pm 2.60^{\mathrm{a}}$ & $46.00 \pm 2.30^{\mathrm{c}}$ \\
\hline V. & DMBASVL1000 & $48.66 \pm 1.66^{\mathrm{a}}$ & $14.33 \pm 0.66^{\mathrm{a}}$ & $43.00 \pm 3.50^{\mathrm{c}}$ \\
\hline VI. & DMBA E.P 500 & $73.66 \pm 2.33^{\mathrm{ac}}$ & $15.46 \pm 4.39^{\mathrm{a}}$ & $50.00 \pm 0.00^{\mathrm{a}}$ \\
\hline VII. & DMBA E.P1000 & $32.66 \pm 1.66^{\mathrm{a}}$ & $15.00 \pm 1.15^{\mathrm{a}}$ & $43.33 \pm 1.33^{\mathrm{c}}$ \\
\hline VIII. & DMBA BW500 & $49.00 \pm 18.00^{\mathrm{a}}$ & $8.13 \pm 4.37^{\mathrm{bc}}$ & $42.00 \pm 2.40^{\mathrm{c}}$ \\
\hline IX. & DMBABW1000 & $38.66 \pm 1.76^{\mathrm{a}}$ & $11.00 \pm 0.00^{\mathrm{a}}$ & $44.00 \pm 1.15^{\mathrm{c}}$ \\
\hline
\end{tabular}

Table 1: Results of liver function enzymes of DMBA treated rats, when given aqueous extract of the various plants. Values are expressed as Mean \pm SEM. Values in a column with the same alphabetical superscript do not differ significantly $(\mathrm{p} \leq 0.05)$.

\begin{tabular}{|c|c|c|c|}
\hline $\mathrm{S} / \mathrm{N}$ & Groups & TB $(\mu \mathrm{mol} / \mathrm{L})$ & $\mathrm{CB}(\mu \mathrm{mol} / \mathrm{L})$ \\
\hline I. & Control & $12.96 \pm 2.16^{\mathrm{a}}$ & $7.26 \pm 1.49$ a \\
\hline II. & DMBA & $15.43 \pm 1.61^{b}$ & $8.53 \pm 1.41^{\mathrm{a}}$ \\
\hline III. & DMBA STD & $13.60 \pm 0.60^{\mathrm{a}}$ & $8.10 \pm 0.80^{a}$ \\
\hline IV. & DMBASVL500 & $13.56 \pm 1.23^{\mathrm{a}}$ & $8.93 \pm 1.46^{\mathrm{a}}$ \\
\hline V. & DMBASVL1000 & $13.86 \pm 1.06^{a}$ & $8.50 \pm 0.69 \mathrm{a}$ \\
\hline VI. & DMBA E.P 500 & $19.00 \pm 0.50$ ac & $13.43 \pm 0.69 \mathrm{abc}$ \\
\hline VII. & DMBA E.P1000 & $10.43 \pm 0.82^{\mathrm{a}}$ & $6.46 \pm 1.08 \mathrm{a}$ \\
\hline VIII. & DMBA BW500 & $15.36 \pm 2.57^{b}$ & $9.10 \pm 1.06^{\mathrm{a}}$ \\
\hline IX. & DMBA BW1000 & $11.53 \pm 0.16^{\mathrm{a}}$ & $6.80 \pm 0.36^{a}$ \\
\hline
\end{tabular}

Table 2: Bilirubin concentration of DMBA treated rats, when given aqueous extract of the various plants.

Values are expressed as Mean \pm SEM. Values in a column with the same alphabetical superscript do not differ significantly $(\mathrm{p} \leq 0.05)$.

\begin{tabular}{|c|c|c|c|}
\hline S/N & Groups & Total Protein(g/L) & Albumin(g/L) \\
\hline I. & Control & $69.33 \pm 1.45^{\mathrm{a}}$ & $32.33 \pm 0.88^{\mathrm{a}}$ \\
\hline II. & DMBA & $73.66 \pm 2.60^{\mathrm{a}}$ & $31.66 \pm 0.88^{\mathrm{a}}$ \\
\hline III. & DMBA STD & $72.33 \pm 2.02^{\mathrm{a}}$ & $34.00 \pm 0.57^{\mathrm{a}}$ \\
\hline IV. & DMBASVL500 & $75.00 \pm 3.78^{\mathrm{a}}$ & $37.00 \pm 1.15^{\mathrm{ab}}$ \\
\hline V. & DMBASVL1000 & $71.00 \pm 1.00^{\mathrm{a}}$ & $34.00 \pm 0.56^{\mathrm{ab}}$ \\
\hline VI. & DMBA E.P 500 & $68.00 \pm 2.08^{\mathrm{a}}$ & $34.66 \pm 1.20^{\mathrm{a}}$ \\
\hline VII. & DMBA E.P1000 & $70.66 \pm 3.84^{\mathrm{a}}$ & $38.00 \pm 2.30^{\mathrm{ab}}$ \\
\hline VIII. & DMBA BW500 & $72.00 \pm 0.15^{\mathrm{a}}$ & $35.56 \pm 2.60^{\mathrm{a}}$ \\
\hline IX. & DMBA BW1000 & $69.33 \pm 0.33^{\mathrm{a}}$ & \\
\hline
\end{tabular}

Table 3: Albumin and total protein concentration of DMBA treated rats, when given aqueous extract of the various plants. Values are expressed as Mean \pm SEM. Values in a column with the same alphabetical superscript do not differ significantly $(\mathrm{p} \leq 0.05)$. 


\section{International Journal of Biochemistry \& Physiology}

\begin{tabular}{|c|c|c|}
\hline S/N & Groups & GGT(U/L) \\
\hline I. & Control & $4.43 \pm 0.53^{\text {a }}$ \\
\hline II. & DMBA & $5.53 \pm 0.37^{\text {a }}$ \\
\hline III. & DMBASTD & $6.83 \pm 1.18^{\text {a }}$ \\
\hline IV. & DMBAGLC500 & $5.53 \pm 1.10^{\text {a }}$ \\
\hline V. & DMBAGLC1000 & $6.13 \pm 0.41^{\text {a }}$ \\
\hline VI. & DMBA E.poly500 & $4.83 \pm 0.68^{\text {a }}$ \\
\hline VII. & DMBA E.poly1000 & $5.16 \pm 0.96^{\text {a }}$ \\
\hline VIII. & DMBA BW500 & $3.60 \pm 0.96^{\text {a }}$ \\
\hline IX. & DMBA BW1000 & $2.60 \pm 0.05^{\text {a }}$ \\
\hline
\end{tabular}

Table 4: GGT(U/L) Activity of DMBA treated rats, when given aqueous extract of the various plants.

Values are expressed as Mean \pm SEM. Values with similar alphabetical superscript do not differ significantly $(p \leq 0.05)$ among the groups.

\section{Kidney function test}

Kidney function test of DMBA administered albino rats, given aqueous concentrate of the different plants on Table 5.

For uric acid concentration, DMBA STD $(668.00 \pm 107.89 \mu \mathrm{mol} / \mathrm{L})$ was significantly increased $(\mathrm{p} \leq 0.05)$ than the control $(418.66 \pm 55.31 \mu \mathrm{mol} / \mathrm{L}), \mathrm{DMBA}$ E.P $500(473.00 \pm 15.09 \mu \mathrm{mol} / \mathrm{L}), \quad$ DMBA E.P1000 $(427.33 \pm 41.59 \mu \mathrm{mol} / \mathrm{L})$, DMBA BW.500 $(431.50 \pm 45.50$ $\mu \mathrm{mol} / \mathrm{L})$ and DMBA BW1000 $(376.66 \pm 4.40 \mu \mathrm{mol} / \mathrm{L})$ groups.

\begin{tabular}{|c|c|c|c|}
\hline Groups & Uric acid $(\boldsymbol{\mu m o l} / \mathbf{L})$ & $\mathbf{C r}(\boldsymbol{\mu m o l} / \mathbf{L})$ & Urea(mmol/L) \\
\hline Control & $418.66 \pm 55.31^{\mathrm{a}}$ & $167.66 \pm 15.40^{\mathrm{a}}$ & $7.73 \pm 0.57^{\mathrm{bc}}$ \\
\hline DMBA & $569.66 \pm 44.30^{\mathrm{a}}$ & $159.36 \pm 15.40^{\mathrm{b}}$ & $10.73 \pm 0.60^{\mathrm{b}}$ \\
\hline DMBA STD & $668.00 \pm 107.89^{\mathrm{c}}$ & $203.66 \pm 6.06^{\mathrm{c}}$ & $11.00 \pm 0.40^{\mathrm{b}}$ \\
\hline DMBASVL500 & $511.33 \pm 94.41^{\mathrm{a}}$ & $180.00 \pm 9.23^{\mathrm{a}}$ & $9.66 \pm 1.30^{\mathrm{a}}$ \\
\hline DMBASVL1000 & $550.66 \pm 51.89^{\mathrm{a}}$ & $175.30 \pm 2.02^{\mathrm{a}}$ & $7.73 \pm 0.49^{\mathrm{bc}}$ \\
\hline DMBA E.P 500 & $473.00 \pm 15.09^{\mathrm{a}}$ & $156.67 \pm 13.56^{\mathrm{a}}$ & $7.70 \pm 1.90^{\mathrm{bc}}$ \\
\hline DMBA E.P1000 & $427.33 \pm 41.59^{\mathrm{a}}$ & $197.00 \pm 5.19^{\mathrm{c}}$ & $11.00 \pm 0.70^{\mathrm{b}}$ \\
\hline DMBA BW500 & $431.50 \pm 45.50^{\mathrm{a}}$ & $174.00 \pm 7.57^{\mathrm{a}}$ & $10.56 \pm 1.21^{\mathrm{a}}$ \\
\hline DMBA BW1000 & $376.66 \pm 4.40^{\mathrm{a}}$ & $165.30 \pm 0.88^{\mathrm{a}}$ & $9.70 \pm 0.64^{\mathrm{a}}$ \\
\hline
\end{tabular}

Table 5: Kidney function indices of DMBA treated albino rats, given aqueous extract of the various plants.

Values are stated as Mean \pm SEM. Values in a column with alike alphabetical superscript do not contrast significantly $\mathrm{p} \leq 0.05$.

For Creatinine concentration, DMBA STD $(203.66 \pm 6.06 \mu \mathrm{mol} / \mathrm{L})$ was significantly higher $(\mathrm{p} \leq 0.05)$ than the DMBA untreated $(159.36 \pm 15.40 \mu \mathrm{mol} / \mathrm{L})$ group. The other groups showed no noteworthy difference $(\mathrm{p} \leq 0.05)$.

The concentration of Urea in control $(7.73 \pm 0.57$ $\mathrm{mmol} / \mathrm{L})$, DMBASVL1000 (7.73 $\pm 0.49 \mathrm{mmol} / \mathrm{L})$ and DMBA E.P $500(7.70 \pm 1.90 \mathrm{mmol} / \mathrm{L})$ was significantly lessened $(p \leq 0.05)$ when contrasted to the DMBA-untreated $(10.73 \pm 0.60 \mathrm{mmol} / \mathrm{L})$ and DMBASTD $(11.00 \pm 0.40$ $\mathrm{mmol} / \mathrm{L})$ groups. DMBASVL500 $(9.66 \pm 1.30 \mathrm{mmol} / \mathrm{L})$ was also reduced (but not noteworthy, $\mathrm{p} \leq 0.05$ ) when contrasted to the DMBA untreated group $(10.73 \pm 0.60$ $\mathrm{mmol} / \mathrm{L})$ and DMBA STD group (11.00 $\pm 0.40 \mathrm{mmol} / \mathrm{L})$.

\section{Electrolyte Determination}

Electrolytes concentration of DMBA administered albino rats, given aqueous concentrate of the different plants is appeared on Table 6. The concentration of sodium $\left(\mathrm{Na}^{+}\right)$in DMBA E.P1000 $(157.33 \pm 2.40 \mathrm{mmol} / \mathrm{l})$ and DMBA B.W.1000 (163.33 $\pm 2.02 \mathrm{mmol} / \mathrm{l})$, was altogether lessened $(p \leq 0.05)$ when juxtaposed with the control $\quad(188.00 \pm 7.81 \mathrm{mmol} / \mathrm{l}), \quad$ DMBA $(187.00 \pm 1.15 \mathrm{mmol} / \mathrm{l})$ and DMBASTD $(184.66 \pm 6.74 \mathrm{mmol} / \mathrm{l})$ groups. DMBASVL1000 group was 


\section{International Journal of Biochemistry \& Physiology}

likewise essentially lessened $\quad(\mathrm{p} \leq 0.05) \quad$ when differentiated to the control $(188.00 \pm 7.81 \mathrm{mmol} / \mathrm{l})$ and DMBA $(187.00 \pm 1.15 \mathrm{mmol} / \mathrm{l})$ groups. For Potassium $\left(\mathrm{K}^{+}\right)$, bicarbonate $\left(\mathrm{HCO}_{3}^{-}\right)$and chloride $\left(\mathrm{Cl}^{-}\right)$concentration, there was no noteworthy difference $(p \leq 0.05)$ among the groups.

\begin{tabular}{|c|c|c|c|c|}
\hline Groups & $\mathbf{N a}^{+}(\mathbf{m m o l} / \mathbf{L})$ & $\mathbf{K}^{+}(\mathbf{m m o l} / \mathbf{L})$ & $\mathbf{H C O}_{\mathbf{3}} \mathbf{-}(\mathbf{m m o l} / \mathbf{L})$ & $\mathbf{C l}^{-}(\mathbf{m m o l} / \mathbf{L})$ \\
\hline Control & $188.00 \pm 7.81^{\mathrm{a}}$ & $4.20 \pm 0.96^{\mathrm{a}}$ & $24.00 \pm 1.15^{\mathrm{a}}$ & $64.66 \pm 6.83^{\mathrm{a}}$ \\
\hline DMBA & $187.00 \pm 1.15^{\mathrm{a}}$ & $3.36 \pm 0.95^{\mathrm{a}}$ & $21.00 \pm 9.07^{\mathrm{a}}$ & $67.00 \pm 1.52^{\mathrm{a}}$ \\
\hline DMBA STD & $184.66 \pm 6.74^{\mathrm{a}}$ & $4.26 \pm 1.13^{\mathrm{a}}$ & $21.00 \pm 9.07^{\mathrm{a}}$ & $64.00 \pm 6.80^{\mathrm{a}}$ \\
\hline DMBASVL500 & $191.66 \pm 7.26^{\mathrm{a}}$ & $5.93 \pm 0.82^{\mathrm{a}}$ & $26.67 \pm 0.66^{\mathrm{a}}$ & $73.33 \pm 5.54^{\mathrm{a}}$ \\
\hline DMBASVL1000 & $167.00 \pm 2.88^{\mathrm{ab}}$ & $2.90 \pm 0.60^{\mathrm{a}}$ & $29.00 \pm 0.57^{\mathrm{a}}$ & $75.00 \pm 0.02^{\mathrm{a}}$ \\
\hline DMBA E.P 500 & $191.00 \pm 3.78^{\mathrm{a}}$ & $5.76 \pm 2.14^{\mathrm{a}}$ & $26.67 \pm 1.76^{\mathrm{a}}$ & $73.33 \pm 15.45^{\mathrm{a}}$ \\
\hline DMBA E.P1000 & $157.33 \pm 2.40^{\mathrm{abc}}$ & $3.30 \pm 0.95^{\mathrm{a}}$ & $26.00 \pm 2.30^{\mathrm{a}}$ & $74.33 \pm 3.84^{\mathrm{a}}$ \\
\hline DMBA BW500 & $172.00 \pm 9.86^{\mathrm{a}}$ & $2.93 \pm 0.03^{\mathrm{a}}$ & $29.00 \pm 0.57^{\mathrm{a}}$ & $57.50 \pm 7.50^{\mathrm{a}}$ \\
\hline DMBA BW1000 & $163.33 \pm 2.02^{\mathrm{abc}}$ & $2.68 \pm 0.85^{\mathrm{a}}$ & $28.00 \pm 1.15^{\mathrm{a}}$ & $53.00 \pm 1.15^{\mathrm{a}}$ \\
\hline
\end{tabular}

Table 6: Electrolytes concentration of DMBA treated albino rats, given aqueous extract of the various plants.

Values are stated as Mean \pm SEM. Values in a column with alike alphabetical superscript do not contrast significantly $\mathrm{p} \leq 0.05$.

\section{Determination of bone markers}

Table 7 demonstrates the Result of bone markers of DMBA treated wistar rats, when given aqueous extract of the various plants. For $\mathrm{Ca}^{2+}$ concentration within the groups, all the treated groups aside from DMBA BW500 and DMBA BW1000 was altogether lower $(\mathrm{p} \leq 0.05)$ than the control and DMBA groups. While for acid phosphatase (AP) $(\mathrm{U} / \mathrm{L})$ activity, there was no significant distinction $(\mathrm{p} \leq 0.05)$.

\begin{tabular}{|c|c|c|}
\hline Groups & $\mathbf{C a}^{2+}(\mathbf{m m o l} / \mathbf{L})$ & $\mathbf{A P ( U / L )}$ \\
\hline Control & $2.56 \pm 0.14^{\mathrm{a}}$ & $3.20 \pm 0.05^{\mathrm{a}}$ \\
\hline DMBA & $2.20 \pm 0.20^{\mathrm{a}}$ & $2.43 \pm 0.29^{\mathrm{a}}$ \\
\hline DMBA STD & $1.20 \pm 0.09^{\mathrm{ab}}$ & $2.46 \pm 0.07^{\mathrm{a}}$ \\
\hline DMBASVL500 & $1.19 \pm 0.11^{\mathrm{ab}}$ & $2.80 \pm 0.11^{\mathrm{a}}$ \\
\hline DMBASVL1000 & $1.29 \pm 0.07^{\mathrm{ab}}$ & $2.60 \pm 0.23^{\mathrm{a}}$ \\
\hline DMBA E.P 500 & $1.71 \pm 0.30^{\mathrm{ab}}$ & $2.33 \pm 0.32^{\mathrm{a}}$ \\
\hline DMBA E.P1000 & $1.19 \pm 0.11^{\mathrm{ab}}$ & $2.93 \pm 0.14^{\mathrm{a}}$ \\
\hline DMBA BW500 & $2.35 \pm 0.02^{\mathrm{a}}$ & $2.83 \pm 0.20^{\mathrm{a}}$ \\
\hline DMBA BW1000 & $1.86 \pm 0.03^{\mathrm{a}}$ & $2.83 \pm 0.11^{\mathrm{a}}$ \\
\hline
\end{tabular}

Table 7: Result of bone markers of DMBA treated wistar rats, when given aqueous extract of the various plants. Values are stated as Mean \pm SEM. Values in a column with alike alphabetical superscript do not contrast significantly $\mathrm{p} \leq 0.05$.

\section{Discussion}

Cancer is a class of diseases in which a group of cells display uncontrolled growth, invasion and sometimes metastasis to other locations in the body via lymph or blood [13]. Breast cancer originates from the breast tissue, most commonly from inner lining of milk ducts (DCIS) or lobules (LCIS) that supply the ducts with milk which are prone regions for tumor microenvironment [1]. Breast cancer can metastasize to different organs of the body, especially tissues, such as, the bone, lung, liver and brain [14]. Thus determining liver and bone biomarkers is of significance. Table 1-4 demonstrates the consequences of Liver function test of DMBA treated albino rat, given aqueous concentrate of the different plants.

The AST activity of all groups were essentially diminished $(\mathrm{p} \leq 0.05)$ when juxtaposed with DMBA untreated animals $(63.33 \pm 8.56 \mathrm{U} / \mathrm{L})$ aside from those animals incited with tumour using DMBA and treated with $500 \mathrm{mg} / \mathrm{kg} \quad$ Eremomastax polysperma $(73.66 \pm 2.33 \mathrm{U} / \mathrm{L})$. Whereas the ALT activity of all treated groups were significantly lower $(p \leq 0.05)$ than DMBA untreated animals $(30.66 \pm 0.66 \mathrm{U} / \mathrm{L})$. ALT is a biomarker 


\section{International Journal of Biochemistry \& Physiology}

of hepatocellular injury and a rise in plasma level is indicative of an injury to the cytoplasmic membrane in the cell. AST is utilized to monitor the cause of various liver disorders [15]. This suggests the concentrates had no hepatoxicity. The ALP activity of all treated animals were significantly reduced $(\mathrm{p} \leq 0.05)$ when compared to DMBA untreated group $(52.00 \pm 2.30 \mathrm{U} / \mathrm{L})$ except for those animals induced with DMBA and treated with $500 \mathrm{mg} / \mathrm{kg}$ Eremomastax polysperma $(50.00 \pm 0.00 \mathrm{U} / \mathrm{L})$. Elevated levels of Alkaline phosphatase may be due to intrahepatic obstruction or extrahepatic obstruction, or if it is present in serum in large amounts, it is diagnostic of bone or liver disease or a tumour in these organs [15]. This study indicates the extracts except $500 \mathrm{mg} / \mathrm{kg}$ Eremomastax polysperma do not have effect on the enzyme activity, thus may not cause hepatic injury and possibly no metastasis to the bones. The ALT and AST. activities reduction is in accordance but in contrast in ALP activity with those of Wang and Zhang [16], which showed a significantly reduced ALT, AST and ALP activities when treated with Honokiol of DMBA-induced breast tumour animals. ArroyoAcevedo, et al.[17], additionally completed a comparable work utilizing $P$. auduncum case and demonstrated that it could lessen ALT activity and demonstrated no critical disparity in ALP activity.

The total bilirubin concentration of those animals induced with tumour using DMBA and treated with a standard drug (Tamoxifien) $(13.60 \pm 0.60 \mu \mathrm{mol} / \mathrm{L})$, $500 \mathrm{mg} / \mathrm{kg}$ Sorghum vulgare leaf sheath $(13.56 \pm 1.23$ $\mu \mathrm{mol} / \mathrm{L}), \quad 1000 \mathrm{mg} / \mathrm{kg}$ Sorghum vulgare leaf sheath $(13.86 \pm 1.06 \mu \mathrm{mol} / \mathrm{L}), \quad 1000 \mathrm{mg} / \mathrm{kg} \quad$ E. polysperma $(10.43 \pm 0.82 \mu \mathrm{mol} / \mathrm{L})$ and $1000 \mathrm{mg} / \mathrm{kg}$ Brillantaisia owariensis $(11.53 \pm 0.16 \mu \mathrm{mol} / \mathrm{L})$ was significantly reduced $(\mathrm{p} \leq 0.05)$ when compared with DMBA animals $(15.43 \pm 1.61 \mu \mathrm{mol} / \mathrm{L})$.

But for conjugated bilirubin concentration, there was no critical distinction $(p \leq 0.05)$ in all groups aside from those animals treated with $500 \mathrm{mg} / \mathrm{kg}$ of Eremomastax polysperma $(13.43 \pm 0.69 \mu \mathrm{mol} / \mathrm{L})$ which had a fundamentally high value $(\mathrm{p} \leq 0.05)$ when contrasted with the different groups. Increased levels of total bilirubin demonstrate jaundice [15]. This manner validates that the concentrate possesses no deleterious impact on total bilirubin and conjugated bilirubin concentration. The total bilirubin concentration of this present study was higher than Baccharis dracunculifolia $(3.42 \mu \mathrm{mol} / \mathrm{l})$ [18] but lower than Punica granatum (18.29-22.25 $\mu \mathrm{mol} / \mathrm{l})$ [19] treated mammary tumorigenic animals.
For the albumin and total protein concentrations, there was no striking contrast $(\mathrm{p} \leq 0.05)$ within the groups for the total protein concentrations. While there was huge increment $(p \leq 0.05)$ in albumin concentration of animals actuated with DMBA and treated with $500 \mathrm{mg} / \mathrm{kg}$ guinea corn leaf sheath $(37.00 \pm 1.15 \mathrm{~g} / \mathrm{l}), 1000 \mathrm{mg} / \mathrm{kg}$ of Sorghum vulgare leaf sheath $(37.33 \pm 0.66 \mathrm{~g} / \mathrm{l})$ and $500 \mathrm{mg} / \mathrm{kg}$ Eremomastax polysperma $(38.00 \pm 2.30 \mathrm{~g} / \mathrm{l})$ when contrasted with the control $(32.33 \pm 0.88 \mathrm{~g} / \mathrm{l})$ and DMBAuntreated animals $(31.66 \pm 0.88 \mathrm{~g} / \mathrm{l})$. Other groups had higher values than DMBA and the control groups, although not significant $(p \leq 0.05)$. Serum proteins, such as albumin denotes malnutrition and identification of response to inflammation. In breast cancer patients, hypoalbuminemia does occur with values $<3.0 \mathrm{~g} / \mathrm{dl}[20]$. This shows the plants concentrate may not pose hepatic damage since the concentration of albumin and total protein were within range and may be viable in hoisting hypoalbuminemia that may happen in breast tumour patients. The total protein and albumin concentration of this study was similar to those of Kakehashi, et al. [18], which demonstrated that total protein and albumin was $68-69 \mathrm{~g} / \mathrm{l}$ and $31-34 \mathrm{~g} / \mathrm{l}$ respectively, in tumorigenic wistar rats. Although it was higher than those animals treated with Punica granatum (albumin as $27.2-31.8 \mathrm{~g} / \mathrm{l}$ and total protein as $42.4-54.6 \mathrm{~g} / \mathrm{l})$ [19].

For GGT activity (Table 4), there was critical decline $(\mathrm{p} \leq 0.05)$ for those animals treated with $500 \mathrm{mg} / \mathrm{kg}$ Brillantaisia owariensis (3.6U/L) when analogised with the control $(4.43 \mathrm{U} / \mathrm{L})$ and the DMBA $(5.53 \mathrm{U} / \mathrm{L})$ groups. There was no critical distinction $(p \leq 0.05)$ among other groups, in spite of the fact that there was diminished values in the animals treated with $500 \mathrm{mg} / \mathrm{kg}$ Eremomastax polysperma (4.83U/L) when compared to the DMBA (5.53U/L) animals. Elevated serum intensities of GGT are markers of oxidative stress (particularly in carcinogenesis) [21]. The diminished valuations of the treated group, shows the concentrates could decrease oxidative stress that would have been activated by DMBA harm. The GGT activity decrease is as per those of Wang and Zhang [16], which demonstrated a lessened GGT activity when treated with Honokiol of DMBA-instigated breast tumour animals.

The kidney work test of DMBA administered albino animals, given aqueous concentrate of the different plants is appeared on Table 5. There was no huge distinction $(\mathrm{p} \leq 0.05)$ in the uric acid concentration of all the groups aside from the animals treated with a standard medication (Tamoxifen), which had essentially higher values $(\mathrm{p} \leq 0.05)$ when juxtaposed with the control (Table 


\section{International Journal of Biochemistry \& Physiology}

5). Uric acid is connected seriously with renal disappointment and cardiovascular illness, hypertension and metabolic disorder [22].

The creatinine and urea concentration was higher fundamentally $(\mathrm{p} \leq 0.05)$ in those animals treated with the standard drug and $1000 \mathrm{mg} / \mathrm{kg}$ Eremomastax polysperma when compared to the DMBA (creatinine) and control (urea). The urea concentration of animals treated with $1000 \mathrm{mg} / \mathrm{kg}$ Sorghum vulgare leaf-sheath and $500 \mathrm{mg} / \mathrm{kg}$ Eremomastax polysperma was significantly reduced $(p \leq 0.05)$ when compared to the DMBA untreated group and those groups treated with a standard drug (Tamoxifen). The reduction of urea concentration by the plants extract, supports the claims of Arroyo-Acevedo, et al. [17]; that P. auduncum capsule was able to reduce urea concentration when contrasted to the untreated group, in DMBA-induced mammary tumour. The creatinine concentration of all the groups in this study was higher than those of Soliman and Elfeky [23], which demonstrated the creatinine concentration of Ginger and cinnamon as $55.70 \mu \mathrm{mol} / \mathrm{l}$ and $59.24 \mu \mathrm{mol} / \mathrm{l}$ respectively of breast cancer rats. Also, the uric acid concentration (84.46-94.57 $\mu \mathrm{mol} / \mathrm{l}$ ) of this present study was higher than the DMBA-incited animals treated with Holothuria atra [24]. Furthermore, it is similarity to the works of Ibrahim, et al. [25] for uric acid and urea concentration but dissimilar for creatinine concentration of animals incited with tumour using DMBA and treated with Brassica oleracea was lower than the DMBA untreated group.

Table 6 demonstrates the Electrolytes concentration of DMBA administered albino animals, given aqueous concentrate of the different plants. There was striking diminution $(\mathrm{p} \leq 0.05)$ in the $\mathrm{Na}^{+}$concentration for the animals treated with $1000 \mathrm{mg} / \mathrm{kg}$ Sorghum vulgare leaf sheath, $1000 \mathrm{mg} / \mathrm{kg}$ Eremomastax polysperma, and $1000 \mathrm{mg} / \mathrm{kg}$ Brillantaisia owariensis. Low sodium concentration, below $120 \mathrm{mEq} / \mathrm{l}$ is usually found in breast cancer patients [26]. This indicates no breast cancer since all the $\mathrm{Na}^{+}$values were above $120 \mathrm{mEq} / \mathrm{l}$. For $\mathrm{K}^{+}$ concentration, the DMBA group had lower concentration however not huge $(p \leq 0.05)$ when juxtaposed with the control, animals treated with standard medication, $500 \mathrm{mg} / \mathrm{kg}$ S. vulgare group and $500 \mathrm{mg} / \mathrm{kg}$ E. polysperma group. Hypokalemia do happen because of danger in breast malignancy patients while hyperkalemia is a marker of renal failure difficulty $[27,26]$. The $\mathrm{HCO}_{3}$ concentration for all groups was within range (24$30 \mathrm{mmol} / \mathrm{L}$ ) except for the DMBA-untreated group and the animals treated with standard medication which possessed lower than normal values showing acidosis, in spite of the fact that there was no huge contrast $(p \leq 0.05)$. There was no striking variance $(\mathrm{p} \leq 0.05)$ in the chloride concentration within the groups. In contrast to the works of Kakehashi, et al. [18], who stated that the electrolyte concentration of tumorigenic animals treated with ethanolic extract of Bacchaaris dracunculifolia for $\mathrm{Cl}^{-}$ $(99.1 \pm 3.3-101.1 \pm 3.0 \mathrm{mEq} / \mathrm{L})$, and $\mathrm{Na}^{+} \quad(142.6 \pm 1.9$ $142.1 \pm 1.9 \mathrm{mEq} / \mathrm{l})$ was lower than the results gotten from this study, whereas the $\mathrm{K}^{+}(4.0 \pm 0.3-4.8 \pm 1.5 \mathrm{mEq} / \mathrm{L})$ was higher than the results of this present study except for the animals treated with $500 \mathrm{mg} / \mathrm{kg}$ of E. polysperma which had higher $\mathrm{K}^{+}$value.

As earlier stated, one of breast cancer metastatic site is the bones. Bone markers include alkaline phosphatase, calcium and acid phosphatase. Table 7, demonstrates the ACP (U/L) activity of DMBA administered albino rats, given aqueous concentrate of the different plants. There was noteworthy decrease $(p \leq 0.05)$ in animals treated with the standard drug when juxtaposed with the DMBA un-treated animal and the control; other groups demonstrated no huge difference $(p \leq 0.05)$. Acid phosphatase (AP) is a marker of prostate growth [28] and of metastatic bone malady in patients with cancer of the breast [29]. Normal serum range of acid phosphatase is 2.5 to $3.7 \mathrm{ng} / \mathrm{ml}$. From the study, there was no bone metastasis since the AP activity of all the groups was within the normal range. This study differs with those of Gopikrishnan, et al. [30] which demonstrated that Naringin was able to reduce Acid phospahtase activity of DMBA induced mammary carcinogenic rats when contrasted with the DMBA untreated group [31-35].

The $\mathrm{Ca}^{2+}(\mathrm{mmol} / \mathrm{l})$ concentration of DMBA treated albino rats, given aqueous extract of the various plants is shown on Table 7 also. There was significant reduction $(\mathrm{p} \leq 0.05)$ in $\mathrm{Ca}^{2+}$ concentration (which was below normal $2.0-2.6 \mathrm{mmol} / \mathrm{L}$ ) of animals treated with standard medication, $500 \mathrm{mg} / \mathrm{kg}$ Sorghum vulgare leaf-sheath, $1000 \mathrm{mg} / \mathrm{kg}$ Sorghum vulgare leaf sheath and $1000 \mathrm{mg} / \mathrm{kg}$ Eremomastax polysperma when juxtaposed with the DMBA untended animal and the control. Indicating there might be slight kidney damage if not properly checked but there may not be bone metastases since there was no increase beyond the normal range. In contrast, Kakehashi, et al. [18] stated that the electrolyte concentration of tumorigenic animals treated with ethanolic extract of Bacchaaris dracunculifolia for $\mathrm{Ca}^{2+}$ was10.7 $\pm 0.4-$ $10.6 \pm 0.4 \mathrm{mEq} / \mathrm{L}$, which is higher than all the treated groups in this study [35-42]. 


\section{International Journal of Biochemistry \& Physiology}

\section{Conclusion}

In conclusion, the aqueous extract of the plants' poses no hepatotoxic injury and was able to increase the albumin and total protein concentration.

\section{References}

1. Mani G, Arumugam M, Maril A, Devaki T (2018) Naringin attenuates DMBA-Induced Mammary carcinogenesis in rats via regulating the oxidative stress and antioxidant status. J Chem Pharma Res 10(7): 44-54.

2. Desai AG, Qazi GN, Ganju RK, El-Tamer M, Singh J, et al. (2008) Medicinal Plants and cancer chemoprevention. Current Drug Metabolism 9(7): 581-591.

3. Nazario HE, Lepe R, Trotter FJ (2011) Metastatic Breast Cancer Presenting as Acute Liver Failure. Gastroent Hepat 7(1): 65-66.

4. Oyetayo FL, Ogunrotimi AI (2012) Guinea Corn (Sorghum vulgare) Leaf, a Potential Source of Nutrients and Phytochemicals. Food Public Health 2(6): 228-230.

5. Akuru UB, Amadi BA (2018) Phytochemicals and antioxidant properties of some selected medicinal plants. J Pharmacog Phytochem 7(5): 283-285.

6. Faparusi F, Bello-Akinosho, Oyede RT, Adewole A, Bankole PO, et al. (2012) Phytochemical screening and antibacterial activity of Brillantaisia patula leaf. Res J Phytochem 6(1): 9-16.

7. Ugoh EA, Chukwurah PN, Ita EE, Chukwudi U (2015) Potential of selected spice and medicinal plants in southern Nigeria as raw material for food and drug industries. J Biotechnol Biomater 5(2): 40.

8. Johnkennedy N, Dike-ndudim J, Elendu HN, Nwagbaraocha M, Egbuobi R, et al. (2013) Antioxidant and Cardioprotective effect of Coconut water against Doxorubicin induced cardiomyopathy. J Krishna Inst Med Sci Univ 2(2): 37-41.

9. Barros ASCD, Muranaka K, Mori JL, Pelizon CHT, Kyoshi I, et al. (2004) Induction Of Experimental Mammary Carcinogenesis In Rats With 7,12dimethylbenz(a)anthracene. Rev Hosp Clín Fac Med S Paulo 59(5): 257-261.
10. Maruna RFL (1958) Colometric determination of sodium in human serum and plasma. Clini Chem Acta 2: 581 .

11. Trinder P (1951) Determination of sodium in serum. Analyst 76: 596.

12. Hillman GZ (1971) Clinical chemistry. Biochem 9: 273.

13. Jagatheesh $\mathrm{K}$, Arumugam $\mathrm{V}$, Elangovan $\mathrm{N}$, PavanKumar P (2010) Evaluation of the Anti-Tumor and Antioxidant Activity of Amorphophallus Paeonifolius on DMBA Induced Mammary Carcinoma. Int J Chem Pharma Sci 1(2): 40-50.

14. Tabariès S, Siegel PM (2011) Breast Cancer Liver Metastasis. In: Brodt (Ed.), Liver Metastasis: Biology and Clinical Management, Cancer Metastasis - Biology and Treatment. 16(10): 273-303.

15. Arika WM, Nyamai DW, Osano KO, Ngugi MP, Njagi ENM (2016) Biochemical Markers of In Vivo Hepatotoxicity. J Clin Toxicol 6(2): 1-8.

16. Wang Z, Zhang X (2017) Chemopreventive Activity of Honokiol on DMBA-induced mammary cancer in female Sprague Dawley rats. Frontiers in Pharmac 8(320): 1-11.

17. Arroyo-acevedo J, Chávez-asmat JR, Anampa-Guzmán A, Donaires R, Ráez-Gonzáles J (2015) Protective Effect of Piper aduncum Capsule on DMBA induced Breast Cancer in Rats. Breast Cancer: Basic Clini Res 9: 41-48.

18. Kakehashi A, Ishii N, Fujioka M, Doi K, Gi M, et al. (2016) Ethanolic-extracted Brazillian propdis exerts protective effects on tumorigenesis in wistar Hanna rats. Plos One 11(7): 1-7.

19. Ahmed M, Ashor B, Fahim H, Aouzid F, Gaber A, et al. (2016) Punica granatum mitigates 7,12dimethylbenz(a)anthracene and $\mathrm{CCl}_{4}$ induced oxidative stress and hepatic precancerous lesions in wistar rats. Indo Ame J Pharmaceu Res 6(7): 64936510.

20. Tsai H, Hsieh M, Tsai Y, Liu Z, Hsieh H, et al. (2013) Liver function test maybe useful tools for advanced cancer patient care: A pulmonary single center results. Elsevier 30(3): 146-152. 


\section{International Journal of Biochemistry \& Physiology}

21. Fentiman IS (2012) Gamma-glutamyl transferase: risk and prognosis of cancer. British J Cancer 106(9): 1467-1468.

22. Ryoo J, Choi J, Oh C, Kim M (2013) The Association between Uric Acid and Chronic Kidney Disease in Korean Men: A 4-Year Follow-up Study. J Korean Med Sci 28(6): 855-867.

23. Soliman M, Elfeky S (2016) Studies on biochemical and molecular effects of some natural herbs on experimental-induced breast cancer in wistar rats. Nat J Physio Pharam Pharmac 6(5): 349-358.

24. Dakroy AF, Fahmey RS, Soliman AM, Mohammed AS, Amer SAM (2015) Protective ans curative effects of sea cucumber Holothuria atra extract against DMBAinduced hepatorenal disease in rats. Biomed Res Int: 1-11.

25. Ibrahim MMC, Youners R, El-Neway S, Ibrahim Y, Kashak WA (2017) Modulating effect of brassica oleracea L. var. itallica extract in chemically induced mammary carcinomas in rats. Biosci Res 14(2): 331346.

26. Shirali A (2016) Chapter 5: Electrolyte and Acid-Base Disorders in Malignancy. Ame Soc Nephrol 1-7.

27. Gowda S, Desai PB, Kulkarni SS, Hull VV, Math AAK, et al. (2010) Markers of renal function tests. N Ame J Med Sci 2(4): 170-173.

28. Bull H, Murray PG, Thomas D, Fraser AM, Nelson PN (2002) Acid phosphatases. Molecu Pathol 55(2): 6572.

29. Halaby R, Abdollahi J, Martine M (2001) Acid Phosphatase Activity in Human Breast Tumor. Biomed Central 2(14): 1-7.

30. Gopikrishnan M, Arumugam M, Maril A, Devaki T (2018) Naringin attenuates DMBA-Induced Mammary carcinogenesis in rats via regulating the oxidative stress and antioxidant status. J Chem Pharma Res 10(7): 44-54.

31. Daniel WV, Nassar A, Degnim CA, Frost MH, Robert $\mathrm{AV}$, et al. (2014) Sclerosing adenosis and risk of breast cancer. Breast Cancer Res Treat 144(1): 205212.

32. Directorate of Laboratory Medicine (DLM) (2008) Specimen requirements and reference ranges for blood analyses (Adults). Central Manchester and Manchester Children's University Hospital: 42-90.

33. Guray M, Sahin AA (2006) Benign Breast Diseases: Classification, Diagnosis, and Management. Oncologist 11(5): 435-449.

34. Hartmann LC, Amy C, Degnim MD, Richard J, Santen MD, et al. (2015) Atypical Hyperplasia of the Breast Risk Assessment and Management Options. N Engl J Med 372(1): 78-89.

35. Hasan R, Abdul B (2012) Medicinal plants (Importance and uses). Pharmaceu Anal Acta 3(10): 2153-2435.

36. Jacobs WT, Byrne C, Graham C, James LC, Schnitt SJ (2001) Pathologic Features of Breast Cancers in Women With Previous Benign Breast Disease. Ame Soc Clini Pathol 115: 362-369.

37. Nelson DL, Cox MM (2005) Lehninger principles of biochemistry. $4^{\text {th }}$ (Edn.) 2(22): 47-70; 854-857.

38. Philip H, Johnny C (2012) What is the real function of the liver function tests. Ulster Med J I 81(1) 30-36.

39. Salarieh A, Sneige N (2007) Breast Carcinoma Arising in Microglandular Adenosis A Review of the Literature. Arch Pathol Lab Med 131: 1397-1399.

40. Szasz G, Bergmeyer HU (1974) Gamma Glutamyltranspeptidase. Methods of Enzymatic analysis. Weinheim Vertag Chemie. 2nd (Edn.), pp: 757.

41. Teitz NN (1987) Fundamentals of Clinical Chemistry. $3^{\text {rd }}$ (Edn.), Philadelphia, W.B. Saunders Co. pp: 391.

42. Thalia MTA, Storch AS, Castro AL, Azevedo VMMG, Ferraz L, et al. (2015) Oxidative stress in the pathophysiology of metabolic syndrome: which mechanisms are involved (A review). J Bras Patol Med Lab 51(4): 231-239.

Akuru UB, et al. Effect of Aqueous Extract of Selected Plants on Liver, Bone and Kidney Markers of 7,12-Dimethylbenz(A)Anthracene (DMBA) Treated Albino-Rats. Copyright@ Akuru UB, et al. Int J Biochem Physiol 2019, 4(2): 000150. 